CUADERNOS DE ESTUDIOS GALLEGOS, LXII Núm. 128 (enero-diciembre 2015), págs. 83-105

ISSN: $0210-847 \mathrm{X}$

DOI: 10.3989/ceg.2015.128.03

\title{
THE ROYAL CHAPEL DURING THE REIGN OF KING JOÃO I (1385-1433): THE ROLE OF ITS CLERGYMEN*
}

\author{
Maria Helena da Cruz Coelho \\ Universidade de Coimbra
}

* This paper is supported by FEDER through the Program COMPETE and by National Funds through the FCT in the scope project «DEGRUPE - The European Dimension of a Group of Power: Ecclesiastics and the political State Building of the Iberian Monarchies $\left(13^{\text {th }}-15^{\text {th }}\right.$ centuries $) »$, with the reference FCT «PTDC/EPH-HIS/4964/2012». 


\section{THE ROYAL CHAPEL DURING THE REIGN OF KING JOÃO I (1385-1433): THE ROLE OF ITS CLERGYMEN}

\section{AbSTRACT}

In this work we will study essentially the ecclesiastical members of king João I's royal chapel. We will begin by presenting a list containing the number and category of the clerics who constituted it, and their respective salaries. We discriminate the functions of its principal members - head chaplain, singers, almoner - and give particular attention to the king's confessors, recruited among the mendicant friars, who played a fundamental role in the court's adoption of lines of spirituality and devotion, as well as in the kingdom's politics, due to their proximity to the king and the royal family. We then take a closer look at the political-religious dimension of this organ, stressing the influence exerted by those clergymen on the king - both at the personal level, acquiring assets, positions, benefits and privileges, and in their contribution to defining and carrying out the kingdom's policies.

KEY WORDS: Reign of João I, king of Portugal; royal chapel; clergymen in the king's service; Franciscan and Dominican confessors.

\section{LA CAPILLA REAL EN EL REINADO DE JUAN I DE PORTUGAL (1385-1433): EL PAPEL DE SUS CLÉRIGOS}

RESUMEN

A lo largo de estas páginas se estudia a los eclesiásticos al servicio de la capilla real de don Juan I de Portugal. En primer lugar, se da a conocer una lista que representa el número y categoría de clérigos que la componían, así como sus respectivos salarios; se detallan las funciones de sus principales miembros, tales como capellán mayor, cantores o limosnero; y se presta especial atención a los confesores del rey reclutados entre los mendicantes, los cuales tenían un papel fundamental tanto en la adopción de las líneas de espiritualidad y devoción de la corte, como también por su proximidad con el rey y la familia real en la política del reino. A continuación, se profundiza en la dimensión político-religiosa de este órgano, poniendo de relieve el peso de estos religiosos próximos al rey, tanto a nivel personal, consiguiendo bienes, cargos, beneficios y privilegios, como en su contribución para la definición y concreción de la política del reino. Palabras Clave: Reinado de don Juan I, rey de Portugal; capilla real; clérigos al servicio del rey; confesores franciscanos y dominicos.

\section{A CAPELLA REAL NO REINADO DE XOÁN I DE PORTUGAL (1385-1433): O PAPEL DOS SEUS CLÉRIGOS}

RESUMO

Ao longo destas páxinas estúdase os eclesiásticos ao servizo da capela real de don Xoán I de Portugal. En primeiro lugar, dáse a coñecer unha lista que representa o número e categoría de clérigos que a compoñían, así como os seus respectivos salarios; detállanse as funcións dos seus principais membros, tales como capelán maior, cantores ou esmoleiro; e préstase especial atención aos confesores do rei recrutados entre os mendicantes, os cales tiñan un papel fundamental tanto na adopción das liñas de espiritualidade e devoción da corte, coma tamén pola súa proximidade co rei e a familia real na política do reino. A continuación, afóndase na dimensión político-relixiosa deste órgano, poñendo de relevo o peso destes relixiosos próximos ao rei, tanto a nivel persoal, conseguindo bens, cargos, beneficios e privilexios, como na súa contribución para a definición e concreción da política do reino.

Palabras Clave: Reinado de don Xoán I, rei de Portugal; capela real; clérigos ao servizo do rei; confesores franciscanos e dominicanos. 
Recibido/Received: 13/03/2015

Aceptado/Accepted: 07/07/2015

$\mathrm{T}$

he Portuguese Royal Chapel, a court organization which had begun to form in the $13^{\text {th }}$ century, was already quite consolidated a hundred years later ${ }^{1}$. The founding king of the Avis dynasty will thus inherit this organization, with its inherent positions and services, although during his rule some new tendencies will begin to take shape, to be fully developed throughout the reigns of his successors ${ }^{2}$.

But before we proceed let us make clear that, although the name «chapel» refers not only to the liturgical objects used in the cult, but also to the space assigned to it in the royal palace, and to the ecclesiastical personnel ascribed to its service, in this article we will focus essentially on this last aspect in the palace chapel ${ }^{3}$.

\section{THE CHAPEL IN THE CONTEXT OF KING'S HOUSEHOLD}

King João I, following his marriage, set up the royal households. Taking advantage of the presence of noblemen and men from the municipalities who had come to the royal wedding, he convened the Cortes - the Portuguese medieval parliament - in the city of Porto, possibly from the $15^{\text {th }}$ to the $23^{\text {rd }}$ of February 1387. In this meeting, decisions were made concerning both the king's and the queen's households, although no description of either one has come down to us.

\footnotetext{
1 Rita Costa Gomes, A Corte dos Reis de Portugal no final da Idade Média, Lisboa, Difel, 1995, pages 28-29, 110-120. Confront the evolution of the palace chapel in the crown of Leon and Castile in David Nogales Rincón, "Las capillas y capellanías reales castellano-leonesas en la Baja Edad Media (siglos XIII-XV): algunas precisiones institucionales", Anuario de Estudios Medievales, 35/2 (2005), pages 748-750.

2 Ivo Carneiro de Sousa argues that it is with the Avis dynasty that the Portuguese Royal Chapel presents an organized and institutionalized structure that is fixed definitively with Afonso V (Ivo Carneiro de Sousa, "Capela Real", in Carlos Moreira Azevedo (dir.), Dicionário de História Religiosa de Portugal, A-C, Lisboa, Círculo de Leitores, 2000, pages 286-288).

3 We did not consider other types of royal chapels in the present study. About the differences in institutional, liturgical, ceremonial, semantic and spacial terms between the royal chapel of the palace and the royal chapels in cathedrals, abbeys or others, similar to other individuals, and primarily intended for funerary celebrations read David NogaLes Rincón, "Las capillas y capellanías reales castellano-leonesas..." pages 749-750.
} 
The court, structured around the king and sharing the royalty's material and symbolic spaces ${ }^{4}$, was made up of institutions and personnel who accompanied the twofold performance - public and private - incarnated in the monarch's person ${ }^{5}$.

Thus, while the aula was an open chamber, resulting from the king's encounter with his vassals and servants, which brought together the officials dealing with justice, administration and military organization, the camara was the organ which signalled delimitation and control of access to the presence of the king. The chapel was the institution which channelled the religious life of the court, while accumulating, in its early days, the all - important function of written memory the chancery. The court's evolution was marked, in the $14^{\text {th }}$ and $15^{\text {th }}$ centuries, by a progressive rationalization and bureaucratization, which led to the separation of the existing functions, each assigned to its own official.

\subsection{The chapel's clergymen}

The chapel was a clerical organism which accompanied the court, its clergymen being in charge of the king's, and his courtiers', religious cult. The constitution of king João I's chapel is disclosed to us in greater detail through a listing of his household staff, made around $1402^{6}$. This document also gives us some information on the queen's household - although regrettably nothing on her chapel - and certain notes regarding the officials who accompanied the princes D. Duarte, D. Pedro and D. Henrique, although here again nothing is said of religious services.

Thus we learn that, in addition to the head chaplain, there were another 14 people among chaplains and singers. To this number were added 8 moços da capela (young assistants), which gives a total of 23 people. This was already beyond the prescribed figure, which was set at 15 people.

We also know that the head chaplain, who at the time was João Lourenço, received 3000 pounds, while 13 of the chaplains were rewarded with 1200 pounds each and the remaining one with 1000 pounds only. Each moço da capela, in turn, got half of a chaplain's pay, that is, 600 pounds.

\footnotetext{
4 Rita Costa Gomes, op. cit., pages 7-43.

5 Ernst Kantorowicz, The king's two bodies. A study in political medieval theology, Princeton, Princeton University Press, 1957.

6 This document is undated, but a critical date has been established for it. In Monumenta Henricina, I, doc. 122, it is given the date of 1402 , before the $29^{\text {th }}$ of September - birthday of D. Fernando, a prince who is still not mentioned in the document (Monumenta Henricina, ed. by Comissão Executiva das Comemorações do IV Centenário da Morte do infante D. Henrique, 15 vols., Coimbra, Almedina, 1960-1974, from now on quoted as $M H$ ). Jorge de Faro, in turn, gives us the time interval 1405-1406 (Jorge Faro, Receitas e Despesas da Fazenda Real de 1394 a 1481. (Subsidios Documentais), Lisboa, Fundação do Centro de Estudos Económicos, 1965, doc. 5). Some discrepancies occur between the two publishers' transcriptions of the documents. We will follow the version in Monumenta Henricina.
} 
When we compare these figures with those relating to the other court dwellers, we see that 1200 pounds was the amount received by the lowest paid squires, from a group of $45^{7}$. The head chaplain's pay, on the other hand, was much higher than that of most squires ${ }^{8}$, being equivalent to that of the king's household accountant.

On his side, the king's chief almoner earned 5000 pounds ${ }^{9}$ and the queen's almoner 2000 - a figure close to, although a bit lower than, the compensation of her escrivão da puridade (personal secretary) ${ }^{10}$.

All these figures will be more easily understood with the explanation that follows.

\subsection{The social and religious profile of the chapel's clergymen}

The complex structure of the royal chapel included chaplains, singers and moços da capela, under the direction of the head chaplain. These clergymen were chosen by the king and removable. Serving in the royal chapel does not seem to have resulted in its members ascending to high positions in the Church hierarchy, especially when compared to some officials of the Desembargo - the body of the central administration. However, chaplains and singers were graced with the accumulation of different benefices under royal protection, often remaining exempt from their inherent obligations ${ }^{11}$. Thus the monarch could easily recruit the best clergymen, without having to compensate them with substantial pay.

The head chaplain was a clergyman of prestige, powerful in the ecclesiastical sphere - involving the royal patronage and the direction of the chapels attached to the king's residences - but also influential in the courtly sphere. Due to his importance, he no longer carried out daily activities in the chapel, reserving himself for liturgical rituals and solemn or festive ceremonials.

Up to the end of the $14^{\text {th }}$ century, they were recruited essentially from the secular clergy, but in later times their origin could be in the regular clergy as well. Some of king João I's head chaplains whose names we know - Martim Gonçalves, Martim Lourenço, Afonso Anes, João Lourenço do Porto and Frei Lourenço Afonso - are clear proof of this possibility, as they are of the association between episcopal dignity and this courtly position.

\footnotetext{
7 On the whole, 28 squires received above 2000 pounds, 15 were paid 2000 pounds, and 12 squires got between 1200 and 2000 pounds.

8 In fact, 72 squires received between 1200 and 2000 pounds.

9 There was however another almoner, his subordinate, whose pay (moradia) was 1500 pounds.

${ }^{10}$ He received 2300 pounds.

${ }^{11}$ Already king D. Pedro had in the past requested to the Pope that 12 clergymen in his service, chosen by him, might enjoy the revenue of all their benefits without having to live on site (Rita Costa GOMES, op. cit., page 110).
} 
In fact, Mestre João Lourenço do Porto was a canon regular of Santa Cruz from 1402 to 1417; and Frei Lourenço Afonso was a master of Theology, nonresident bishop of Mégara and commendatary abbot of Pendorada, serving as head chaplain in the 1420's ${ }^{12}$. The latter's case is good illustration of the great prestige attained by head chaplains in the Avis dynasty ${ }^{13}$.

It should be noted that many of king João's chaplains, in the beginning of his reign, were recruited among the Benedictine monks - the oldest, most traditional monastic strain, which nonetheless showed at the time certain signs of decadence ${ }^{14}$.

We have been able to determine that at least three chaplains belonged to the order of Saint Benedict - Afonso Martins, abbot of Pendorada ${ }^{15}$, Afonso Martins, abbot of Rendufe ${ }^{16}$, the abbot of Refóios de Basto in $1385^{17}$ - and another chaplain who was a canon regular, the abbot of Vilela in $1390^{18}$. As it happens, many of these abbots were absent from the institutions they governed, because they had been recruited as royal chaplains. This process of absenteeism, and their appropriation of monastic revenue, did much to accentuate the decline of these monasterial houses.

In fact, the growing weight of ceremonials in liturgy and court rituals demanded a more sustained intervention by the royal chapel, not compatible with the performance of other ecclesiastical duties. At the same time, however, this

\footnotetext{
${ }^{12}$ Idem, ibidem, page 114. Joseph Soares da Sylva, Memorias para a Historia de Portugal que comprehendem o governo delrey D. Joaõo I do anno de mil e trezentos e oitenta e tres, até o anno de mil e quatrocentos e trinta e tres, vol. II, Lisboa Occidental, Officina de Joseph Antonio da Sylva, 1731, pages 566-568 adds as chaplains to the king - Martim Gonçalves; Frei Aimaro, confessor to the king and the queen; Álvaro Lisboa, a confessor as well; Frei Agostinho de Santa Mónica, an Englishman who had also been the queen's confessor and her chief almoner; and, as chaplain to the queen, bishop D. Lourenço, prior of Folques.

${ }^{13}$ Frei Manoel da Esperança, Historia Serafica da Ordem dos Frades Menores de S. Francisco na Provincia de Portugal, $2^{\mathrm{a}}$ parte, Lisboa, Oficina de Antonio Craesbeeck, 1666, pages 685-686 says it was franciscan and also confessor of King.

${ }^{14}$ Let us remember that king D. João I and prince D. Duarte requested Pope Martin V to allow the monastery of Pendorada to be reformed with 18 monks from Italy, with permission to elect their abbot, ensuring that the commendation granted to D. Lourenço, bishop of Mégara, had been revoked (Monumenta Portugaliae Vaticana, vol. IV, Súplicas do Pontificado de Martinho V (anos 8 a 14), published with introduction and notes by António Domingues de Sousa Costa, Braga-Porto, Editorial Franciscana, 1970 (from now on quoted as MPV), docs. 851, 852.

${ }^{15} \mathrm{He}$ ruled the monastery from 1367 and is thought to have built a new cloister, finished in 1382, but he was connected to the court since the days of D. Pedro (Rita Costa GoMES, op. cit., page 112).

${ }^{16}$ Chancelarias Portuguesas. D. João I, org. by João José Alves Dias, 4 vols., 11 ts, Lisboa, Centro de Estudos Históricos da Universidade Nova de Lisboa, 2000-2006 ((from now on quoted as CDJI), vol. I, t. 3, doc. 1379, from Braga, $5^{\text {th }}$ of December 1385.

${ }^{17} C D J I$, vol. I, t. 3, doc.1090, from Guimarães, $13^{\text {th }}$ of November 1387.

${ }^{18} C D J I$, vol. II, t. 1, doc. 47, from Lamego, $15^{\text {th }}$ of January 1390.
} 
more permanent and continued service brought the members of the royal chapel significantly closer to the person of the king, his family and the royal retinue. This in turn fostered an esprit de corps which kept them for a long time in that service ${ }^{19}$.

The prestige attached to the royal chaplaincy is clearly perceived when we know that, in the days of king João, the privileges of the royal chapel were bestowed, honorifically, to the abbot of Pendorada and the prior of the collegiate church of Nossa Senhora da Oliveira, in Guimarães ${ }^{20}$.

Special care was taken in the chapel regarding its singers - they were generally recruited among the moços da capela and instructed within the chapel. King Duarte even drew up a regulation for them ${ }^{21}$. Song and music were prized so highly in the royal chapel, especially in the case of organ players, that the musicians could even become the object of contention among royal courts. This happened in the time of D. Duarte, when a singer and organist was «diverted» to Castile ${ }^{22}$. Ever meticulous, the heir to the throne - still as a prince or already as king - drew up another regulation on chaplains who, during his rule at least, were to take turns in their service. He also prescribed strictly the duration of festive liturgical ceremonies in honour of the Virgin, the Saints or the moveable feasts ${ }^{23}$.

Besides the royal chapel, which followed the court in its itinerations, we should remember that there were other chapels founded by the kings, all with their own chaplains. Some of these chapels had been created for the burial and suffrage of past monarchs ${ }^{24}$, while others, often dedicated to Saint Michael, were scattered among the royal palaces - namely those of Leiria, Santarém, Sintra and Almeirim - clearly showing the importance of liturgical activity in the courtly life of the royal family. But such chapels probably had no more than one or two chaplains, with their assistants, who were nominated by the monarchs and remained under the authority of the head chaplain. These clergymen, just like their lay chapel counterparts, were attached to their chapels, in which they celebrated

\footnotetext{
19 Rita Costa Gomes, op. cit., page 113.

20 Rita Costa Gomes, op. cit., page 114.

${ }^{21}$ Livro dos Conselhos de El-Rei D. Duarte (Livro da Cartuxa), diplomatic editing, transcription of João José Alves DiAs and introduction of António H. de Oliveira MARQuES and João José Alves DiAs, Lisboa, Editorial Estampa, 1982, pages 209-211.

22 Livro dos Conselhos, pages 90-92.

${ }^{23}$ Livro dos Conselhos, pages 213-214; 215-217. We are on the way to "musical chapel", so the musical dimension of the royal chapel, which praised the relationship with the divinity of the monarch in his line of rex sacerdos, which will have full expression in the second half of the fifteenth century and subsequently both in Portugal as in peninsular kingdoms (read David Nogales Rincón, "Las capillas y capellanías reales castellano-leonesas...", pages 743-744).

${ }^{24}$ On the characteristics of these royal chapels that took care of the "spiritual welfare of the dead king”, read David NoGALES Rincón, "Las capillas y capellanías reales castellano-leonesas...”, pages 750-762).
} 
liturgical acts instead of accompanying the court, although some of them might be very important, as was the case of the Almeirim clergymen ${ }^{25}$.

And it was precisely in the chapel of the king's palace in Aldeia Galega (near Alenquer) that the royal head chaplain, João Lourenço do Porto, celebrated the wedding of two members of the monarch's household, applying the royal policy of promoting unions between vassals of the king's household and maidens from the queen's household ${ }^{26}$.

So it was that D. Catarina de Sousa, of the house of D. Filipa, was married by proxy to João Freire de Andrade, a servant to the king, represented by his uncle and procurator, the knight João Álvares Pereira, brother of Nuno Álvares Pereira. On his matrimony, he received from the king 4000 gold dobras and gave the bride, as dowry, 1000 dobras $^{27}$.

\subsection{The almoners and confessors}

Specific functions were assigned, in the chapel, to the almoners and, above all, to the confessors. In 1402, as we have seen, there were three of the former; two of these - the king's and the queen's - were certainly the chief almoners of the kingdom. As in the court of Aragon - and unlike the French and English courts - the post of almoner belonged, in Portugal, to the Cistercian monks. This was possibly due to their tradition as farmers and producers of foodstuffs, hence as distributors of food in times of need, the chief almoner being the abbot of Alcobaça. Such was the case of Frei Estêvão de Aguiar, whom king João I imposed on the monastery and favoured with great benefices ${ }^{28}$. He probably attended the court only for the most important ceremonies, although there was very close intercourse between the king and the abbots - and the monastery - of Alcobaça. The abbot was charged with choosing the almoners who accompanied the monarch most closely.

Also very relevant was the presence of the confessors, who were often the court preachers as well. While it is customary to include them among the officials of the royal chapel, their close proximity to the king also placed them near the servants of the câmara, who accompanied the monarch at all times.

\footnotetext{
${ }^{25}$ João I begs from Pope Martin V that the tithes on the fertile lands in Almeirim, around the palace, be assigned to the chaplains of the Almeirim chaple. They would be collected by the head chaplain, who would then hand them out to the other chaplains. These, then, were evidently his subordinates (MPV, IV, doc. 1398, "15th of June 1429").

${ }^{26}$ Maria Helena da Cruz Coelho, D. João I, o que re-colheu Boa Memória, Lisboa, Temas e Debates, 2005, page 294.

${ }^{27} C D J I$, vol. III, t. 3, doc. 1220, from Aldeia Galega, $10^{\text {th }}$ of March 1417.

${ }^{28}$ Rita Costa Gomes, op. cit., pages 117 e 118, nt. 209.
} 
Kings, queens and princes were free to chose them. King João I recruited them among the reformed mendicant friars ${ }^{29}$, thus partaking in their ideas and purpose of reforming morals and faith. These confessors, enjoying great influence and prestige, were particularly relevant in defining the lines of spirituality, devotion, piety and morals which the royal family adopted, practised and imposed on its courtiers. Advocates of auricular confession, they dwelt fully inside the sphere of the king and queen's closest quarters. Promoting a very intimate and personal brand of faith and devotion, and a penitence dictated by the redeeming humanity of the Christ, they led men to acts of piety and to a very intense, discrete and responsible practice of their faith.

But these mendicant friars were also, in general, very cultivated clergymen, educated in universities and well groomed in Theology. As such, they were charged with the duties of preaching, their influence becoming very relevant in the atmosphere of the court. Issuing from religious communities implanted in the urban milieu, they were familiar with the debates and the ethical and economic controversies concerning certain professional activities and the value of money. This enabled them to advise, at the highest level, the rulers of the kingdom on the moral content of national and even international policies, postulating on possible overseas options or expressing opinions on the major issues discussed in the Roman Curia. As a consequence, they were often chosen as diplomats too, especially when need arose to defend the kingdom's interests in the Pontifical Court.

Among the confessors to king João I were the Franciscans Frei Fernando de Astorga, provincial superior of Portugal ${ }^{30}$, who may have come from the days of king Fernando; Frei Afonso de Alprão, who lived in Italy and composed an Ars Predicandi; Frei João de Xira, Frei Lourenço, Frei Aimaro and Mestre Frei

\footnotetext{
${ }^{29}$ The increase in the number of Franciscans among the monarchs' confessors dated back to previous reigns already. D. Afonso IV had two, D. Pedro one and D. Fernando two: Frei Fernando Astorga and Frei Gomes (Rita Costa Gomes, op. cit., page 119). See also João Francisco Marques, "Franciscanos e Dominicanos Confessores dos Reis Portugueses das duas primeiras dinastias. Espiritualidade e política", in Espiritualidade e corte em Portugal (Séculos XVI a XVIII): Porto, 28 a 30 de Maio de 1992, Porto, Instituto de Cultura Portuguesa, 1993 (Col. Revista da Faculdade de Letras, Anexo V), pages 53-60, consulted inhttp://ler.letras.up.pt/uploads/ficheiros/artigo8031.pdf [consulted: $10 / 02 / 2015]$.

${ }^{30}$ Confronted with the Papal Schism, Frei Fernando takes up the Franciscan custody in Portugal, obeying to Rome and not to Avignon, thus becoming autonomous from the Peninsular obeisance. From then on, Franciscan provincial superiors almost always became royal confessors. Back in 1384, the king had given as a tença (payment) to the Franciscan Fernando Astorga, for as long as he so pleased, all the revenue from his winery in Unhos (Lisboa) CDJI, vol. I, t. 1, doc. 372, undated but registered among documents from the year 1384 .
} 
Francisco ${ }^{31}$, who had university level studies; and the Dominicans Frei Lourenço Lampreia, who was the first prior of the monastery of Batalha, and Frei Vicente de Lisboa, who was also the king's preacher ${ }^{32}$.

To these members of the chapel must be added the court's prelates and clergymen, some of whom could boast studies at the University and great political power. Reaching far beyond their roles as ministers of the cult, they were assiduous members of the king's retinue - sometimes they even belonged to the royal council $^{33}$ - but in the present study their case will not be analyzed.

\section{THE INFLUENCE OF THE CHAPEL'S CLERGYMEN OVER THE KING}

Now that we are familiar with the political and religious dimensions of the king's chapel, we would like to focus our attention on the weight and influence exerted by these clergymen over the monarch, both on a personal level and regarding their contribution to defining and implementing the kingdom's general policies.

Chaplains and confessors were clergymen who enjoyed close proximity to the persons of the king and his family. Some were even admitted to their most intimate sphere, in particular their confessors.

The privilege of direct access to the king and his lineage, and to the members of the court, placed these men in a position specially suited to ask for favours either for themselves and their immediate circles, or for other people, of higher or lower status, who had no transit in the courtly milieu.

\subsection{Personal benefices}

On a personal level, they managed to obtain from the king properties, positions, benefices and privileges. Let us be more specific.

One privilege which these chapel officials appreciated was that of seeing the stain of illegitimate birth wiped away, allowing them to freely inherit their genitors' estates. This was obtained via letters of legitimation.

\footnotetext{
${ }^{31}$ Fr. Fernando da Soledade, Historia Serafica Cronologica da Ordem de S. Francisco na Provincia de Portugal, t. III, Lisboa, Officina de Manoel \& Joseph Lopes Ferreyra, 1705, page 27.

32 Rita Costa Gomes, op. cit., pages 119-120; Margarida Garcez Ventura, O Messias de Lisboa. Um estudo de mitologia política (1383-1415), Lisboa, Edições Cosmos, 1992, page 41; Joseph Soares da SyLVA, op. cit., vol. II, pages 561-566, adds the Franciscan D. Frei Rodrigo, Frei João Dias, Frei Vasco Pereira, Frei Álvaro de Lisboa (later head chaplain to the king) and Mestre Frei João de São Tomás.

${ }^{33}$ Rita Costa Gomes, op. cit., pages 120-129.
} 
For instance, the king's servant and singer Álvaro Lopes, whose father was the ordained clergyman Lopo Peres, received a letter of legitimation from king João I in $1398^{34}$. The same thing happened, in 1418, to prince Henrique's singer Aparício Vasques, son of the priest Vasco Gonçalves de Sortelha ${ }^{35}$. Likewise, a letter of legitimation was granted, in 1419, to the king's moço da capela Gil Afonso, whose father was the clergyman and canon of Viseu, Afonso Gonçalves ${ }^{36}$.

We should note that all of these were the sons of clergymen ${ }^{37}$ and, as a consequence, they were led into ecclesiastical careers by their genitors. They even ascended to the sphere of the court and reached positions which were strengthened by their access to the estate and income of their paternal inheritances, thus further increasing the revenue from their posts.

But these men could also request for themselves positions, properties or special benefices.

So it was that king João I in 1387 donated to his head chaplain, Martim Gonçalves, all the revenue and privileges of his chapel of S. Vicente do Cabo just as had been the case with king Fernando's head chaplain, Vasco Lourenço ${ }^{38}$.

For his part the king's chaplain, Martim Peres, was nominated in 1398 to the church of Santiago de Mouta, in the diocese of Coimbra. From that moment on he was entitled to a part of that church's revenue ${ }^{39}$. In the same way, in 1423 the king's singer Afonso Anes was nominated to the church of Vilar de Frades, in the archdiocese of Braga ${ }^{40}$.

In 1426 king João I begged from Pope Martin V the accumulation of ecclesiastical benefices for his chaplain Luís Anes ${ }^{41}$.

${ }^{34}$ CDJI, vol. II, t. 1, doc. 60, from Évora, $19^{\text {th }}$ of December 1398.

${ }^{35} C D J I$, vol. III, t. 3 , doc. 1020 , from Évora, $18^{\text {th }}$ of January 1418 .

${ }^{36} C D J I$, vol. IV, t. 1 , doc. 235, from Lisboa, $10^{\text {th }}$ of May of 1419. He also legitimates some of the princes' chaplains such as, in 1433, the chaplain to prince D. Pedro, João Gomes, who was also a clergyman's son (CDJI, vol. IV, t. 2, doc. 892, from Aldeia Galega, $28^{\text {th }}$ of April 1433).

${ }^{37}$ Mothers were always referred to as single women, and their names were known. This, however, gives us no information on their social backgrounds.

${ }^{38} C D J I$, vol. I, t. 3, doc. 1231, from Guimarães, $29^{\text {th }}$ of January 1398.

${ }^{39} C D J I$, vol. II, t. 3, doc. 1159, from Porto, $23^{\text {rd }}$ of August 1398.

${ }^{40} C D J I$, vol. IV, t. 2 , doc. 449 , from Sintra, $19^{\text {th }}$ of August 1423 . In this same year the king nominates, in the church of S. Pedro de Penagunte - archdiocese of Braga - prince D. Fernando's chaplain, Pedro Afonso (CDJI, vol. IV, t. 2, doc.419, from Sintra, $11^{\text {th }}$ of August 1423).

${ }^{41} M P V$, I, docs. 962 e 967. Luís Anes was the rector of the church of S. Miguel de Vila Franca, in the diocese of Braga. He held a canonship, with its prebend, in Porto, and to this he wished to add the revenue from another parochial church, for seven years. The princes themselves acted in the same way: prince D. João requested from the Pope the accumulation of benefices for his chaplain, Martinho Ribeiro ( $M P V$, IV, doc. 831). In his turn the king's nephew D. Afonso, count of Ourém, requested that his chaplains and cantors might receive the revenues of their benefices without being obliged to live on site, for as long as they remained in his service (MPV, IV, doc. 1187). 


\subsection{Protection and privileges for their institutions}

Many chaplains and confessors, however, already possessed ecclesiastical dignities - especially in monasteries - a part of whose revenues they took for themselves, as we have specified. What they asked the king, then, was for protection of their institutions, in order to save them from oppression by noblemen. Thus they ensured their proper spiritual and temporal functioning, from which they would benefit greatly. Their functions in the court, and their absence from the religious houses they governed, were further reasons for these requests to the king.

Thus a chaplain to the king, the abbot of the Benedictine monastery of S. João de Pendorada, begged the monarch, who had just been acclaimed in the Cortes held in Coimbra, to defend his institution from abuse by powerful noblemen. These noblemen stayed at monastic houses and among farmers, threatening their families' lives and robbing them of bread, wine and other revenue, situations which king João would not condone ${ }^{42}$. Some months later, this same chaplain also obtained from the king confirmation of the couto of four wells in the Paiva river, where trout and bogas were fished for the monastery, and also of the places where its housekeepers went fishing with nets and traps, paying to the monastery its due rights. These coutos, which the noblemen failed to respect, were henceforward prohibited to them, under a penalty of 6000 soldos payable to the crown ${ }^{43}$.

Likewise another of the king's chaplains, the abbot of the Benedictine monastery of Refóios de Basto (in the archdiocese of Braga), begged for himself and his monastery the protection of the king, who in fact decided to forbid noblemen from staying there and taking foodstuffs and animals for themselves ${ }^{44}$.

Also the king's chaplain Afonso Martins, abbot of the Benedictine monastery of Rendufe, requested for his monastery similar protection from abuse by the nobility, which king João granted him as well ${ }^{45}$.

For his part the king's chaplain and prior of the monastery of Canons Regular of Saint Augustine in Santo Estêvão de Vilela, in the municipality of Paredes, explained to the monarch that, due to wars and abuse by noblemen, his house was experiencing difficulties. King João I ruled that those noblemen could neither stay at the monastery nor claim for themselves either goods or rights ${ }^{46}$.

And when Mestre Lourenço, bishop of Mégara and commendatary abbot of Pendorada, was head chaplain to the king, he requested from João I that the

\footnotetext{
${ }^{42}$ CDJI, vol. I, t. 2, doc. 931, from Coimbra, $10^{\text {th }}$ of April 1385.

${ }^{43} C D J I$, vol. I, t. 3, doc.1193, from Porto, 26 ${ }^{\text {th }}$ of September 1385.

${ }^{44} C D J I$, vol. I, t. 3, doc. 1090, from Guimarães, $13^{\text {th }}$ of November 1385.

${ }^{45} C D J I$, vol. I, t. 3, doc. 1379, from Braga, $5^{\text {th }}$ of December 1387.

${ }^{46} C D J I$, vol. II, t. 1 , doc. 47 , from Lamego, $15^{\text {th }}$ of January 1390.
} 
monastery's farmers and housekeepers be exempt from service to the monarch and the municipalities, which was granted to him $^{47}$.

In addition to these chaplains, favours were requested by some confessors as well.

Frei Fernando de Astorga, confessor to the king and prior of the Benedictine monastery of Paço de Sousa ${ }^{48}$, complained that his institution, besides the damages resulting from warfare, suffered from the abuse of noblemen who stayed at the monastery and demanded provisions from him, unwilling to respect the papal letters which he had already obtained in condemnation of such acts. King João I demanded that the noblemen refrain from such abuse and submit to the Pope's rulings, made public in Braga ${ }^{49}$.

But the powerful abbot of Alcobaça Frei João de Ornelas, who had crucially helped king João in the battle of Aljubarrota with men at arms and supplies thereby earning his nomination for chief almoner - went even further in his requests ${ }^{50}$. Reclaiming the couto granted to the monastery by king Afonso Henriques and his wife D. Mafalda, free of any charge, he wanted to release Alcobaça from any obligation to give kings, queens and princes, when they visited the monastery, three days of feeding, which in fact would amount to a heavy burden given the size of the court's retinue.

King João I's response is a clear indication of his political programme. He declares that kings who are divinely appointed must judge facts truthfully - «que lugar de deus teem deuem Julgar os fectos per uerdade». So he will consider several aspects in his decision. First he makes sure that the carta de couto issued by king Afonso Henriques did not imply any such obligation. He adds that every king must defend religious places and people. And lastly, he stresses the fact that in the monastery of Alcobaça lie buried not only his father but also other kings, queens and princes. This is thus a true royal pantheon, in addition to being a place of hospitality and devotion, which he greatly prizes.

King João makes his decision bearing in mind all these factors but, as he explicitly states, he does it using his supreme power - of his own free will, certain knowledge and absolute power - even if he listens to advice from queen D. Filipa

${ }^{47}$ CDJI, vol. IV, t. 1 , doc. 138, from Évora, $25^{\text {th }}$ of May 1421.

${ }^{48}$ Frei Manoel da EsperanÇA, Historia Serafica..., $2^{\mathrm{a}}$ parte, pages 396, 399, 415.

${ }^{49} C D J I$, vol. III, t. 1, doc. 228, from Porto, $26^{\text {th }}$ of October 1385.

${ }^{50} C D J I$, vol. II, t. 2, doc. 998, from Santarém, $28^{\text {th }}$ of April 1396. One can know some aspects of Friar John Dornelas relations with royalty and their performance in the monastery of Alcobaça in the study of Maria Alegria Fernandes MARQues, "O mosteiro de Alcobaça na transição do século XIV e XV: o protagonismo de D. João Dornelas", in Cister. Espaços, Territórios, Paisagens. Colóquio Internacional. 16-20 Junho 1998, Mosteiro da Batalha, vol. I, Lisboa, Ministério da Cultura-Instituto Português do Património Arquitectónico, 2000, pages 73-80. 
and prince D. Afonso, his firstborn and heir to the throne. He invokes the praise of God, Saint Mary and the whole celestial court, as well as the remission of his sins and those of his ancestors.

The powerful, wise and God-fearing monarch then decides to extinguish this obligation which until then bound the monastery of Alcobaça. But he would allow no one to forget that this house of faith and religion had been erected by royalty, and so he decreed that, as a sign of thanks, whenever the royal couple arrived at the monastery, once a year, they should receive two dozens of capons or hens. This was meant as a perennial tribute to the magnanimity of the superior power of the king, a true lord of lords.

\subsection{Marks on the religious reform}

These clergymen, who were close to the king, left even bigger marks on the religious reform of the country and on its government's political programme.

While, as we have seen, a number of chaplains and confessors interceded for the institutions to which they belonged, others went as far as creating new religious houses, thus reinforcing the presence of Mendicant orders in the kingdom - above all that of Dominicans.

After the battle of Aljubarrota was won, in 1385, king João I decided to express his gratitude to the Virgin Mary, to whom he had prayed so much, for the protection he believed she had granted him. He wished to devote to her a house of prayer, certainly a church in honour of Saint Mary. While in Melgaço, busy with new military campaigns, he was approached by his confessor, the Dominican Frei Lourenço Lampreia ${ }^{51}$, and his counsellor, Doutor João das Regras, who both begged him to build a Dominican monastery instead, assuring him that in it the cult and devotion to the Virgin would be constant. King João I, due to the religious and intellectual prestige enjoyed by Dominicans, acceded to their request. So he ordered the construction - not on the battle site, as he had projected, but in Quinta do Pinhal - of the monastery of Santa Maria da Vitória. This grandiose work, whose construction dragged along throughout his reign, later became the royal pantheon. But as early as 1388 the monarch delivered it to Frei Lourenço and

\footnotetext{
${ }^{51}$ Cfr. Fr. António do Rosário, "Letrados dominicanos em Portugal nos séculos XIII-XV", in Repertorio de Historia de las Ciencias Eclesiasticas en España, vol. 7, Salamanca, Instituto de Historia de la Teología Española, 1979 (Corpus scriptorum sacrorum hispanias. Estudios, 7), page 584, núm. 109. Saul António Gomes, O Mosteiro de Santa Maria da Vitória no século XV, Coimbra, Faculdade de Letras da Universidade de Coimbra-Instituto de História de Arte, 1990; Saul António Gomes, Vésperas Batalhinas. Estudos de História de Arte, Leiria, Edições Magno, 1997; Maria Helena da Cruz Coelho, D. João I..., pages 353- 363.
} 
appointed Doutor João das Regras as the administrator («promotor e requeredor») of the institution ${ }^{52}$.

For his part Frei Vicente de Lisboa, a master in Theology, provincial superior of Castile's and Portugal's Dominican convents, and confessor and preacher to king João I, engaged eagerly in the Dominican reform ${ }^{53}$.

For one thing, he supported the Dominican convent of S. Salvador de Lisboa, founded in 1392 by the bishop of Porto, D. João Afonso da Azambuja. We should note that this initiative had been favoured from the start by king João I, in the previous year, by donating to its founder the patronage of the said church. This, as stated in the letter of donation, was in return for the many services received from the bishop (a member of the royal council) who had already twice put his body at risk («seu corpo em auentura») by travelling to Rome to defend the king's interests ${ }^{54}$.

But Frei Vicente - whom Frei Luís de Sousa later called a saintly and chaste man - actually wished to create a new religious house and, having gathered the necessary companions, needed a place away from the bustling city to establish it. Resorting to the influence of Doutor João das Regras, he obtained from the king the quinta (farmstead) of Benfica where, in 1399, he instituted the first convent of Dominican Observant monks in Portugal, under royal protection ${ }^{55}$. Once again service to the king, in confession and preaching, influenced the kingdom's religious policies. At the same time the monarch placed himself in the service of God, by supporting the Church's reform.

Later on Frei Vicente, although already advanced in years, agreed to travel to Rome at the request of king João I, to deal with crown matters in the Curia. But he fell ill on his way there, and ended up dying around $1401^{56}$.

While thanks to the two Dominican confessors the force of the Preachers was increased with new houses, the efforts of the Franciscan confessor Frei

\footnotetext{
${ }^{52} C D J I$, vol. I, t. 3, doc. 1339, from Porto, $4^{\text {th }}$ of April 1388.

${ }^{53} \mathrm{He}$ studied and taught at Oxford and was inquisitor of Portugal and the Iberian Peninsula (Fr. António do RosÁrio, "Letrados dominicanos...", page 597, núm. 165).

${ }^{54} C D J$, vol. II, t. I, doc. 405 , from Leiria, $1^{\text {st }}$ of July 1391. At stake was a difficult and morose issue: to free the king from his religious vows and to legitimate his birth, in order to ensure the legitimacy of the royal lineage and succession. Bernardo Vasconcelos E Sousa (dir.), Ordens Religiosas em Portugal. Das Origens a Trento-Guia Histórico, Lisboa, Livros Horizonte, 2005, page 394; Frei Luís de Sousa, História de S. Domingos, vol. I, introduction and e review of M. Lopes de Almeida, Porto, Lello \& Irmão-Editores, 1977, liv. 2, cap. 1, page 812.

${ }^{55}$ Frei Luís de Sousa, História de S. Domingos..., liv. 2, cap. I, pages 813-814 and following chapters. ${ }^{56}$ Frei Luís de Sousa, História de S. Domingos..., liv. 2, caps. IV e V, pages 825-834. We should note that Frei Luís de Sousa mentions his passing on the $5^{\text {th }}$ of January 1401, but then he presents the inscription on his tombstone - set up in the convent when his remains came to Portugal - and there the date of his death is given as the year 1405 .
} 
João de Xira supported another monastic institution, this time belonging to the Franciscan Order. He obtained - with the help of queen Filipa - the construction of the monastery of Santa Clara do Porto ${ }^{57}$.

And so on March 28 1416 , in Porto, after the Ceuta initiative - to which the city had given such great contribution, besides Frei João de Xira himself, with his counsel and preaching, and not least queen Filipa, with her diplomacy and encouragement, until her death on the eve of the expedition - a solemn procession to the place of Carvalhos do Monte, where the convent was settled definitively.

Among the participants, wearing all their festive attire, were D. Fernando da Guerra, bishop of Porto, D. Lourenço Afonso, bishop of Mégara, head chaplain to the king, Frei João, bishop of Morocco, the canons of the Cathedral and the Franciscan and Dominican friars, besides members of the royal family, such as prince D. Fernando and D. Afonso, count of Barcelos, and high courtiers, to lay down the building's first stones. During the ceremony was read the papal decree which authorized the convent's creation, and the bishop of Morocco sang Mass, while the preaching was done by the bishop of Mégara ${ }^{58}$.

King João I could not but grant the request of his confessor, frei João de Xira, who had involved himself so deeply in his political projects.

Confessors and chaplains also had power and influence over the monarch to interfere in the appointment of bishops and monasterial superiors, as well in recommending prebends. And they even obtained some of those posts for themselves. For instance the Franciscan Observant D. Aimaro, confessor to the queen, and her chancellor until the last decade of the $14^{\text {th }}$ century ${ }^{59}$, was made bishop of Morocco in 1413 and, in the year 1421, bishop of Ceuta, the new Portuguese diocese created in the preceding year ${ }^{60}$. As prelate of Ceuta, but also as administrator of the monastery of Pombeiro, he obtained from king D. João I, in 1423, a letter of confirmation of the couto of Pombeiro, and several others in Celorico de Basto, which belonged to the said monastery ${ }^{61}$.

\footnotetext{
${ }^{57}$ Frei Manoel da EsperançA, Historia Serafica..., $1^{\text {a }}$ parte, pages 572-574. He also reformed the convent of Alenquer (Idem, ibidem, page 371).

${ }_{58}$ CDJI, vol. III, t. III, doc. 1189, from Sintra, 20th of May of 1415. See Ordens Religiosas, pages 294-295; Maria Helena da Cruz Coelho, D. João I..., page 290.

${ }^{59}$ Some sources also mention him as head chaplain to king João I, which we were unable to verify through documentation, and later on to king Duarte, until his death in 1444 (Rita Costa Gomes, op. cit., page 115).

${ }^{60}$ Maria Helena da Cruz Coelho, D. João I..., pages 189, 286. Other aspects of his biography presents Frei Manoel da Esperança, Historia Serafica..., $1^{\mathrm{a}}$ parte, page 358, $2^{\mathrm{a}}$ parte, pages 531, 561, 596, 642, 689-691.

${ }^{61} C D J I$, vol. IV, t. 2, doc. 468, from Santarém, $11^{\text {th }}$ February 1423.
} 


\subsection{Influences on government's political programme}

The knowledge and oratory skills of the Mendicants were utilized by the crown to support its policies with advice and preaching, and also to defend its interests in diplomatic missions - to the Roman Curia above all.

A clear, paradigmatic example of this political and diplomatic involvement is the above-mentioned confessor to the king, D. João de Xira ${ }^{62}$.

The project of conquering Ceuta, which lay dormant for several years after peace between Portugal and Castile was signed in 1411, enjoyed from the start the support of the confessors to king João I and prince D. Duarte, Frei João de Xira and Vasco Pereira respectively, both of them Franciscans.

The vedor da fazenda (overseer of the crown's estate) João Afonso de Albuquerque proposed the city of Ceuta as the place where Muslims should be attacked. And the princes embraced this endeavour enthusiastically, eager to be made knights in great feats of arms, in the spirit of the Crusade, according to the chronicler Zurara. Withouth dwelling on the multiple reasons and intentions which dictated the Moroccan option ${ }^{63}$, and still according to the author's narrative, king João I decided to investigate, with careful consideration, whether or not such actions would be in God's service.

To this end he summoned a larger than usual council which included, besides his own counsellors, the greatest men of letters in the city, some important personalities from the municipality of Lisbon, and the already mentioned confessors to the king and his heir. In the council he exposed his doubts, asking everyone for study and counsel ${ }^{64}$. The confessors did not take the matter lightly («não tomaram aquele feito com pequeno cuidado») and reflected deeply on the texts and commentaries by the Doctors of the Church on the Holy Scripture. The men of letters were then able to tell the king that God's service had been proven by the divine support that his ancestors on the throne had received in their struggle against Muslims, which had resulted in victories, land possession and expansion of the Christian faith ${ }^{65}$.

Since this assembly in 1415 , the years went by in the hard work of recruiting and supplying the fleet, in maneuvers to appease the Christian kingdoms who

\footnotetext{
${ }^{62}$ See the principal topics of his biography in Maria Alice Pereira Santos, A sociologia da representação político-diplomática no Portugal de D. João I, Lisboa, Universidade Aberta, 2015 ( $\mathrm{PhD}$ thesis), n. 30, pages 369-373.

${ }^{63}$ Maria Helena da Cruz Coelho, D. João I..., pages 228-236.

${ }^{64}$ Gomes Eanes de Zurara, Crónica da Tomada de Ceuta por el-rei D. João I, published by Francisco Maria Esteves Pereira, Lisboa, Academia das Sciencias de Lisboa, 1915 (from now on quoted as CTC), cap. X.

${ }^{65}$ CTC, cap. XI.
} 
feared a Portuguese attack, and in the unexpected illness and death of queen Filipa, who died of the plague on 18th of July 1415.

At last the fleet, all ships festooned, departed from Restelo, on Saint James's day, the $25^{\text {th }}$ of July 1415. Arriving in Lagos on Sunday $28^{\text {th }}$ of July, the king came ashore to address the men, and assigned the preaching to Frei João de Xira.

Zurara states that he spoke not on the king's orders but rather following the rules of his function. His sermon, a display of his vast culture, is filled with quotations from Greek-Roman philosophers and historians - Cicero, Aristotle, Valerius Maximus, Titus Livius - and from Fathers and Doctors of the Church - Saint Leo the Great, Saint Bernard, Saint Thomas Aquinas. It leans on the Old Testament, quoting from the Pentateuch, Deuteronomy, the Historic Books (Maccabees), the Prophetic Books (Ezekiel and Jeremiah), and he makes reference, in the New Testament, to the Gospel according to John and several epistles by Saint Peter and Saint Paul.

The monarch officially reveals the purpose and destination of the journey, until then kept secret and an object of much guessing. He had fought against Christians through no fault or will of his own; now he would fight, by his own decision, against the enemies of the Christian faith, as a knight of Christ.

Frei João de Xira is prompt to announce forgiveness of sins to those who would repent and make penance, and then shows everyone the decree of crusade issued by the Pope. He extolls the mission of the Portuguese, for they would be the first to set foot on African soil to spread the Christian faith - a guarantee of their souls' salvation and of eternal life for those who lost their lives in combat. But this effort would also offer them honour and memory forever. And the omens of that memory had already been announced by astrologers - whom, he declared, were deemed trustworthy by wise men - who were predicting eternal remembrance for these feats. Here we see Frei João vouching for the credibility of the astrologers' lore - when in harmony with the truths of the Christian faith - and at the same time proving that they could be used in the service of royal propaganda ${ }^{66}$.

\footnotetext{
${ }^{66}$ This position was in conformity with the thought of legal scholars of the time. As Jean-Patrice Boudet clearly demonstrates in his study of the Bologna jurist Giovanni da Legnano, astrology and prophecy were used to assist in predicting the future and interpreting history; the author concludes by stating that, in $14^{\text {th }}$ century Italy, and particularly in Bologna, astrology and prophecy were taken as seriously as law (Jean-Patrice BOUDET, "Giovanni da Legnano et la genèse de son interpretation astrologique", in Christine-Barralis, Jean-Patrice Boudet, Fabrice Delivré et Jean Philippe Genet (dir.), Église et État, Église ou État? Les clercs et la genèse de l'État moderne, Roma, Publications de la Sorbonne/École Française de Rome, 2014, pages 347-365). Paola Guerrini, in turn, reinforces this idea with a study of the iconographic representations of Pope-related prophecies, contained in the manuscripts Vaticinia de summis pontificibus (Paola GuERrinI, "Uso e riuso della profezia nel tardo Medioevo. Il caso del Vaticinia de summis pontificibus", in id., pages 391-415).
} 
And the preacher adds that all men should put away any ill disposition in their hearts, or any criticism of the king's intentions or of the brevity of the late queen's exequies. He assured everyone that the king had felt deeply the death of his spouse but, feeling sure of her happiness in the kingdom of heaven, he had shrugged off sadness and tears so that he could, with renewed joy, devote himself to the service and glory of God.

The Franciscan Frei João de Xira thus legitimated and justified, in every way, the crown's political programme of advancing toward Morocco, sweeping aside the doubts and bad omens which lingered over the act. The king, as a knight of Christ, sustained by the Pope with the privileges of a decree of crusade, rehabilitated from his scarce attention to D. Filipa's exequies and legitimated by the wisdom of astrologers, guaranteed to his countrymen fame and glory, on earth and in heaven.

These words, spoken at a time when some members of the fleet were feeling overexcited, others fearful, and yet others wary, had a galvanizing and unifying effect around the monarch and the interests of the kingdom, an effect once again recognized by king João I.

Frei João de Xira and the chief chaplain of King João I, Afonso Eanes, then embarked on the fleet that went to Ceuta. And it was the chaplain who prepared the mosque, where on Sunday, August 25th, the space was christened with a mass, preaching and the solemn investiture of the infants as knights ${ }^{67}$. Frei João de Xira preached a sermon again in praise of God and tribute to all who had participated in the conquest of Ceuta and so forever had reached the $"$ perfect glory and honor» ${ }^{68}$.

In fact the knowledge and the persuasive powers of Frei João de Xira's oratory were well known to him; he had used them before in another political mission on behalf of the Portuguese crown's interests.

Suffice to recall his actions as an ambassador in the Council of Pisa. Some clergymen wished to end the Church's Schism, which had begun in the late 1370's. Around 1408, certain cardinals in the pontifical courts of Rome and Avignon decided to call an ecumenical council to depose the two existing popes - Benedict XIII in Avignon and Gregory XII in Rome - and to elect a new one, who would have authority over the whole of Christendom. After a long period of negotiation, without agreement from either pope, the council eventually got under way in Pisa, on the $25^{\text {th }}$ of March 1409 . It was attended by cardinals, patriarchs, bishops, episcopal delegates, commendators, abbots and representatives of religious orders, Doctors in Theology and Canon Law, representatives of universities and ambassadors of Christendom's kings, princes and republics. The two popes were absent.

\footnotetext{
${ }^{67}$ CTC, cap. XCV.

${ }^{68} C T C$, cap. XCVI.
} 
King João I sent to the council the archbishop of Lisbon, D. João Esteves de Azambuja, the bishop of Lamego, Gonçalo Gonçalves, his head chaplain, Mestre Lourenço Afonso, the Doctors from Bologna Diogo Martins and Lançarote Esteves, and his confessor Mestre Frei João de Xira ${ }^{69}$. Long controversies and contested decisions, such as the election of a new pope, were turned down by both popes in office. This meeting had no practical results, and the Schism would see its end only at the Council of Constance, when the election of Martin V reestablished the unity of the $\mathrm{Church}^{70}$.

The concrete acts of the Portuguese king's ambassadors, and more specifically the role of his chapel's members Mestre Lourenço and Frei João de Xira, are therefore unknown to us ${ }^{71}$. Undoubtedly, they kept high level contacts in ecclesiastical and lay circles, which left them even better prepared to know Christendom both politically - kingdoms and other secular entities - and at the ecclesiastical level of the pontifical court, dioceses and religious orders. All this knowledge they would later put to use back in Portugal, advising king João I in his most important religious and political decisions.

This study is a preliminary effort, which we hope to complete in due time.

But the analysis carried out so far leads us to conclude that the role played by the royal chapel and its officials is vast, and of prime importance.

For one thing, the cult and liturgy of the royal chapel constitutes the model to be followed by the whole court, and to be imitated in the courtiers' private spaces, dictating the lines of religiosity, behaviour and moral values of the royal retinue and the nobility.

But some members of the royal chapel, thanks to their reformist spirit, culture, knowledge and oratory skills, achieved an even higher position and influence over the royalty: they shaped their religious choices which, under king João I, leaned towards the Mendicant friars. From among these were recruited his confessors, sponsoring the foundation of new monastic houses and thereby increasing the power of the religious orders to which they belonged. They served, or then they dictated - we will never be completely sure - the crown's political options of

\footnotetext{
${ }^{69}$ About this embassy and the Pisa council context read Hélène MiLlet, "La participation du Portugal au concile de Pise (1409)", in A igreja e o clero português no contexto europeu. The Church and the portuguese clergy in the european contex, Lisboa, Centro de Estudos de História Religiosa da Universidade Católica Portuguesa, 2005, pages 235-254.

${ }^{70}$ A recent study by Sophie Vallery-Radot brings to our awareness the meaning and importance of the various french delegates' participation in the Council of Constance (Sophie VallerY-RADOT, "Les Français au concile de Constance. Faire entendre sa voix", in Église et État, Église ou État?..., pages 293-307).
} 
overseas expansion and the ways of evangelization. They fought for, and defended, the interests of king and crown in the face of other powers in Christendom, especially in the circles of the Pontifical Court.

On the other hand, such services and their great closeness and familiarity with the king and the royal family were well rewarded. Some of them requested and obtained letters of legitimation, others received donations of property and privileges, and yet others obtained letters of protection and freedom for the institutions which they directed, and from which they received revenue.

All the inner workings of the service rendered by the chapels' clergymen in constructing the kingdom and articulating Christendom can only be fully grasped by broader investigations, such as the project in which we take part. The truth is, there is still a long way to go if we are to gain a deeper knowledge of these clergymen's training, their intellectual and religious trajectories, their revenues and benefices; to weigh their real power and sphere of influence; and to approach the subtlest, least perceptible details concerning the dimension and consequences of their private relationship with the king, the royal family and the court.

\section{BIBLIOGRAPHY}

Boudet, Jean-Patrice, «Giovanni da Legnano et la genèse de son interpretation astrologique», in Christine-Barralis, Jean-Patrice Boudet, Fabrice Delivré et Jean Philippe Genet (dir.), Église et État, Église ou État? Les clercs et la genèse de l'État moderne, Roma, Publications de la Sorbonne/École Française de Rome, 2014, pages 347-365.

Chancelarias Portuguesas. D. João I, org. de João José Alves Dias , 4 vols., 11 ts, Lisboa, Centro de Estudos Históricos da Universidade Nova de Lisboa, 2000-2006.

Coelho, Maria Helena da Cruz, D. João I, o que re-colheu Boa Memória, Lisboa, Temas e Debates, 2005.

Esperança, Frei Manoel da, Historia Serafica da Ordem dos Frades Menores de S. Francisco na Provincia de Portugal, $1^{\mathrm{a}}$ e $2^{\mathrm{a}}$ parte, Lisboa, Oficina de Antonio Craesbeeck, 1656, 1666.

Faro, Jorge, Receitas e Despesas da Fazenda Real de 1394 a 1481. (Subsídios Documentais), Lisboa, Fundação do Centro de Estudos Económicos, 1965.

Gomes, Rita Costa, A Corte dos Reis de Portugal no final da Idade Média, Lisboa, Difel, 1995.

Gomes, Saul António, O Mosteiro de Santa Maria da Vitória no século XV, Coimbra, Faculdade de Letras da Universidade de Coimbra-Instituto de História de Arte, 1990.

Gomes, Saul António, Vésperas Batalhinas. Estudos de História de Arte, Leiria, Edições Magno, 1997.

Guerrini, Paola, «Uso e riuso della profezia nel tardo Medioevo. Il caso del Vaticinia de summis pontificibus», in Christine-Barralis, Jean-Patrice Boudet, Fabrice Delivré et Jean Philippe Genet (dir.), Église et État, Église ou État? Les clercs et la genèse de l'État moderne, Roma, Publications de la Sorbonne/École Française de Rome, 2014, pages 391-415. 
Kantorowicz, Ernst, The king's two bodies. A study in political medieval theology, Princeton, Princeton University Press, 1957.

Livro dos Conselhos de El-Rei D. Duarte (Livro da Cartuxa), ed. de João José Alves Dias e A. H. de Oliveira Marques, Lisboa, Editorial Estampa, 1982.

Marques, João Francisco, «Franciscanos e Dominicanos Confessores dos Reis Portugueses das duas primeiras dinastias. Espiritualidade e política», in Espiritualidade e corte em Portugal (Séculos XVI a XVIII): Porto, 28 a 30 de Maio de 1992, Porto, Instituto de Cultura Portuguesa, 1993 (Col. Revista da Faculdade de Letras, Anexo V), pages 53-60.

Marques, Maria Alegria Fernandes, «O mosteiro de Alcobaça na transição do século XIV e XV: o protagonismo de D. João Dornelas», in Cister. Espaços, Territórios, Paisagens. Colóquio Internacional.16-20 Junho 1998, Mosteiro da Batalha, vol. I, Lisboa, Ministério da Cultura-Instituto Português do Património Arquitectónico, 2000, pages 73-80.

Millet, Hélène, «La participation du Portugal au concile de Pise (1409)», in A igreja e o clero português no contexto europeu. The Church and the portuguese clergy in the european contex, Lisboa, Centro de Estudos de História Religiosa da Universidade Católica Portuguesa, 2005, pages 235-254.

Monumenta Henricina, ed. Comissão Executiva das Comemorações do IV Centenário da Morte do infante D. Henrique, 15 vols., Coimbra, Almedina, 1960-1974.

Monumenta Portugaliae Vaticana, vol. IV, Súplicas do Pontificado de Martinho V (anos 8 a 14), ed. de António Domingues de Sousa Costa, Braga-Porto, Editorial Franciscana, 1970.

Nogales Rincón, David, «Las capillas y capellanías reales castellano-leonesas en la Baja Eda Media (siglos XIII-XV): algunas precisiones institucionales», Anuario de Estudios Medievales, 35/2 (2005), pages 748-750.

Rosário, António do, «Letrados dominicanos em Portugal nos séculos XIII-XV», in Repertorio de Historia de las Ciencias Eclesiasticas en España, vol. 7, Salamanca, Instituto de Historia de la Teología Española, 1979 (Corpus scriptorum sacrorum hispanias. Estudios, 7).

Santos, Maria Alice Pereira, A sociologia da representação político-diplomática no Portugal de D. João I, Lisboa, Universidade Aberta, 2015 (PhD thesis).

Soledade, Fr. Fernando da, Historia Serafica Cronologica da Ordem de S. Francisco na Provincia de Portugal, t. III, Lisboa, Officina de Manoel \& Joseph Lopes Ferreyra, 1705.

Sousa, Bernardo Vasconcelos e (dir.), Ordens Religiosas em Portugal. Das Origens a TrentoGuia Histórico, Lisboa, Livros Horizonte, 2005.

Sousa, Ivo Carneiro de, «Capela Real», in Carlos Moreira Azevedo (dir.), Dicionário de História Religiosa de Portugal, A-C, Lisboa, Círculo de Leitores, 2000, pages 286-288.

Sousa, Frei Luís de, História de S. Domingos, vol. I, ed. de M. Lopes de Almeida, Porto, Lello \& Irmão-Editores, 1977.

Sylva, Joseph Soares da, Memorias para a Historia de Portugal que comprehendem o governo delrey D. Joaõo I do anno de mil e trezentos e oitenta e tres, até o anno de mil e quatrocentos e trinta e tres, vol. II, Lisboa Occidental, Officina de Joseph Antonio da Sylva, 1731. 
Vallery-Radot, Sophie, «Les Français au concile de Constance. Faire entendre sa voix», in Christine-Barralis, Jean-Patrice Boudet, Fabrice Delivré et Jean Philippe Genet (dir.), Église et État, Église ou État? Les clercs et la genèse de l'État moderne, Roma, Publications de la Sorbonne/École Française de Rome, 2014, pages 293- 307.

Ventura, Margarida Garcez, O Messias de Lisboa. Um estudo de mitologia política (1383-1415), Lisboa, Edições Cosmos, 1992.

Zurara, Gomes Eanes de, Crónica da Tomada de Ceuta por el-rei D. João I, ed. de Francisco Maria Esteves Pereira, Lisboa, Academia das Sciencias de Lisboa, 1915. 
